\title{
O HUMOR NA TRADUÇÃO PARA LEGENDAGEM: O CASO DE WOODY ALLEN EM DESCONSTRUINDO HARRY ${ }^{1}$
}

\author{
Maíra Porto Ferreira
}

\section{Introdução}

No presente artigo, será apresentada a análise de algumas sequências de humor verbal do filme "Desconstruindo Harry" (Deconstructing Harry, Woody Allen, 1997, EUA) e de duas de suas traduções, em formato de legendas, para o português do Brasil. O objetivo da análise será constatar se: a) foi possível manter nas legendas em português os mesmos mecanismos linguísticos que construíram as situações de humor no original; e b), em caso positivo, se a manutenção desses mecanismos linguísticos garantiu a construção de uma situação de humor na tradução.

O suporte teórico da análise será constituído pelos pressupostos de Gideon Toury (1980, 1995), um dos principais representantes dos Estudos Descritivos da Tradução; pela teoria semântica do humor de Victor Raskin (1985); e por alguns estudos realizados nas áreas da tradução audiovisual, como os de Jorge Diaz Cintas (2007) e Jan Pedersen (2005, 2007), e da tradução de humor, como os de Marta Rosas (2002) e Jeroen Vandaele (2002). Também complementam a análise as teorias de humor de Sigmund Freud (1905) e Henri Bergson (1900). A teoria de Raskin foi privilegiada porque seu enfoque, como o deste trabalho, é linguístico, enquanto que o de Freud é psicanalítico, e o de Bergson, sociológico. (Para maiores detalhes sobre as outras teorias, ver Ferreira, 2010; França, 2006; e Rosas; 2002.)

Duas traduções serão analisadas: uma realizada para o cinema, por Monika Pecegueiro do Amaral, tradutora de renome no mercado de tradução para legendagem, e outra, para VHS, cujo tradutor permanece desconhecido. A escolha pelo VHS, tecnologia em desuso, se deu pelo fato de o filme analisado nunca ter sido lançado no Brasil em

\footnotetext{
${ }^{1}$ Este trabalho resultou da pesquisa para obtenção do grau de Mestre pelo Programa de Pós-Graduação em Letras da PUC-Rio, em 2010. Resultados preliminares dessa mesma pesquisa foram apresentados no X Encontro Nacional de Tradutores / IV Encontro Internacional de Tradutores realizado na Universidade Federal de Ouro Preto, em 2009.
} 
FERREIRA - O humor na tradução para legendagem...

nenhuma outra tecnologia (DVD, Blu-Ray etc.), sendo esta a versão disponível para o público até os dias de hoje. Vale ressaltar que a análise não será prescritiva, mas sim descritiva, de forma que o objetivo não será fazer julgamentos de valor sobre os trabalhos dos tradutores, mas observar se as situações de humor traduzidas se enquadram nas categorias de humor postuladas pelo teórico selecionado.

\section{Fundamentos Teóricos}

\subsection{Toury e os Estudos Descritivos da Tradução}

Em meados dos anos 1970, Gideon Toury, da Universidade de Tel Aviv, participou da formulação de uma proposta de caráter descritivo para o estudo da tradução, na qual esta era entendida como um fato cultural inserido em seu contexto de recepção; noção que se opõe à visão essencialista (que caracterizava a maioria dos estudos até então desenvolvidos sobre a atividade), a qual buscava especificar o que poderia ou não ser considerado "tradução". Toda e qualquer tradução que seja aceita como tal na cultura de chegada, afirma Toury, merece ser objeto dos estudos descritivos; o importante é não partir de definições pré-concebidas do que seria uma tradução boa ou ruim, pois

qualquer definição a priori, principalmente se baseada em termos essencialistas, que supostamente especificam o que é "inerentemente" tradutório, teria a inatingível pretensão de fixar para sempre as fronteiras de um objeto que se caracteriza exatamente por sua variabilidade: diferenças entre culturas, variação dentro de uma cultura e mudança com o tempo. ${ }^{2}$ (1995: 31 - grifos do autor, tradução minha ${ }^{3}$ )

Como enfatiza Marcia Martins (2003: 32), no paradigma descritivista, as antigas preocupações essencialistas deram lugar a uma visão funcionalista da tradução, que busca entender como a cultura-alvo pode influenciar "nas estratégias que determinam a forma final de uma tradução [...]”. Afinal, é na cultura-alvo que a tradução circula e é aceita (ou não). Por isso, ressalta, o objetivo do pesquisador descritivista é questionar, dentre outras

\footnotetext{
2 “[...] any a priori definition, especially if couched in essentialistic terms, allegedly specifying what is 'inherently' translational, would involve an untenable pretense of fixing once and for all the boundaries of an object which is characterized by its very variability: difference across cultures, variation within a culture and change over time. MAÍRA, SUGIRO Q ESSA CITAÇÃO E AS DEMAIS SEJAM ASPEADAS. NÃO ESQUEÇA DE CORRIGIR TAMBÉM OS ( ).”
}

\footnotetext{
${ }^{3}$ Essa tradução é minha, bem como as demais traduções de obras ainda não publicadas em português.
} 
FERREIRA - O humor na tradução para legendagem...

coisas, quais circunstâncias levaram o tradutor a reproduzir padrões estéticos de sua cultura ou a introduzir nela padrões da cultura-fonte. No presente trabalho, por exemplo, poderemos constatar se as diferentes soluções encontradas nas duas traduções que compõem nosso corpus privilegiaram padrões da cultura-fonte ou da cultura-alvo e se elas conseguiram reproduzir, na tradução, uma situação considerada humorística pela culturaalvo.

Toury buscou ainda ressaltar a importância das abordagens empíricas para o desenvolvimento dos Estudos da Tradução, pois estas, segundo o teórico, são uma etapa vital na evolução de qualquer teoria de tradução, já que têm a função de alimentar e refinar a teoria, que, por sua vez, tem a função de orientar as pesquisas descritivas. Em suas palavras,

estudos cuidadosamente realizados, baseados em corpora bem definidos, ou em conjuntos de problemas, são a melhor maneira de se testar, refutar e, especialmente, modificar e corrigir a própria teoria, cujos pressupostos orientam as pesquisas. ${ }^{4}(1995: 1$ - grifos do autor)

\subsection{Raskin e a Teoria Semântica do Humor}

$\mathrm{Na}$ "teoria dos dois scripts", como é conhecida no Brasil, Victor Raskin (1985) investiga a semântica da linguagem das piadas: o autor classifica aqueles que, a seu ver, são os temas e estereótipos mais comuns nesse tipo de linguagem, e analisa os mecanismos linguísticos que a constroem. Sua teoria, mesmo não englobando o fenômeno do humor em sua totalidade (como o próprio autor reconhece), se mostrou bastante instrumental para a análise de diversos exemplos extraídos da obra de Woody Allen.

Raskin parte de dois pressupostos. O primeiro deles é que, para que uma história seja considerada engraçada, é necessário que ela se mostre compatível, parcial ou totalmente, com dois scripts diferentes (deve haver uma sobreposição de scripts). O segundo, é que esses scripts devem ser semanticamente opostos (1985: 99).

Scripts são definidos como estruturas cognitivas internalizadas; são feixes de informações que armazenamos em nossas mentes, através dos quais organizamos o mundo

\footnotetext{
4 “carefully performed studies into well-defined corpuses, or sets of problems, constitute the best means of testing, refuting, and especially modifying and amending the very theory, in whose terms research is carried out.”
} 
FERREIRA - O humor na tradução para legendagem...

à nossa volta — numa espécie de compartimentalização mental de dados sobre a vida, o mundo, os homens etc. Os scripts podem estar associados a atividades triviais, como as tarefas diárias de acordar, tomar banho, vestir uma roupa e ir trabalhar; a questões do senso comum; e a questões mais profundas, como a vida e a morte, a sexualidade, a religiosidade etc. São eles que nos ajudam a interpretar as situações pelas quais passamos ao longo da vida, nos ajudando a associar certos gestos, atitudes, expressões e emoções a certos feixes de informações, evitando que tenhamos de formular um novo raciocínio a cada passo que damos, pois novas situações são interpretadas a partir de dados armazenados sobre situações já vividas.

Quando ouvimos uma história ambígua, compatível com mais de um script, explica Raskin (1985), tentamos interpretá-la de forma a eliminar a ambiguidade, para definir qual dos scripts sobrepostos está sendo realmente evocado. O receptor da mensagem ambígua vai buscando uma palavra, uma expressão, uma pista, enfim, que indique qual é o script “certo" naquele contexto. A mensagem será humorística se, depois de encontrar essa pista, o receptor se der conta de que o script "certo" é oposto ao que estava, de fato, esperando e a história, ainda assim, faz sentido.

Essa oposição entre script "certo" e "errado" pode ser literal, sendo um script a óbvia negação ou antônimo do outro; ou pode depender do contexto específico da história para ser concebida como tal; são as oposições que Raskin (1985: 108) denomina “antonímias locais". Como podem variar com o contexto, são inúmeras as possibilidades de oposições humorísticas, mas, “grosso modo, as oposições apontadas nas piadas parecem envolver a dicotomia fundamental dos valores humanos em termos de realidade e idealização" (França, 2006: 158 - grifos da autora).

A partir da dicotomia real / ideal, Raskin postula três tipos básicos de oposições. São elas (em minha tradução): situação existente / não existente; situação normal / anormal; situação possível / impossível. ${ }^{5}$ As fronteiras entre as oposições nem sempre são nítidas, dado que "como acontece com qualquer classificação importante, há casos claramente delimitados e casos marginais"6 (1985: 112). Além desses três tipos básicos, há outras dicotomias presentes no humor, as quais representam as poucas categorias binárias

\footnotetext{
${ }_{6}^{5}$ No original, actual $X$ non-actual, normal $X$ abnormal, possible $X$ impossible.

6 " [...] just as in the case of any meaningful classification, there are clear-cut cases and marginal, or borderline, cases [...]."
} 
FERREIRA - O humor na tradução para legendagem...

que o homem considera essenciais à vida: bem / mal (ou bom / ruim); vida / morte; sexual / não-sexual; monetário / não-monetário (ou, ainda, fartura de dinheiro / escassez de dinheiro) ${ }^{7}$.

Além do aspecto semântico (scripts e suas oposições), Raskin ressalta um aspecto pragmático do discurso humorístico: a passagem do modo bona fide de comunicação — o modo sério e honesto, através do qual o falante veicula alguma informação para o ouvinte, respeitando as máximas conversacionais de Grice ${ }^{8}$ — para o modo non-bona fide, cujo propósito "não é veicular nenhuma informação contida no texto que está sendo dito, mas sim causar um efeito especial com a ajuda do texto [...]" (Raskin, 1985: 101). No discurso humorístico, não vigoram as máximas de Grice, não havendo um compromisso com a verdade das informações veiculadas, nem com a clareza das mesmas, que, pelo contrário, devem ser ambíguas. No humor, o primeiro script pertence ao modo bona fide e o segundo, ao non-bona fide, e a passagem de um ao outro se dá através de uma pista dada ao receptor.

As pistas, ou, nos termos de Raskin (1985), gatilhos (triggers), conceito que passarei a empregar daqui por diante, são os elementos linguísticos que sinalizam ao receptor (geralmente, mas não necessariamente, ao fim da piada) que ele está interpretando a mensagem erroneamente e possibilitam que ele passe de um script ao outro. (No caso dos meios audiovisuais, os gatilhos também podem ser elementos visuais ou sonoros.) Inclusive, a partir do momento em que o receptor percebe que está diante de uma mensagem humorística, ele tende a ficar à espera de um gatilho (Chiaro, 1992: 49).

Podemos dizer que todo texto de humor é ambíguo, no sentido de que evoca dois scripts diferentes. Mas Raskin explica que existem dois tipos de gatilhos: os que revelam, de fato, uma ambiguidade (um termo com duplo sentido, por exemplo, que permite duas interpretações) e os que revelam uma contradição (quando uma interpretação acaba negando a outra).

\footnotetext{
${ }^{7}$ No original, good $X$ bad, life $X$ death, obscene $X$ non-obscene, money $X$ no money (much money $X$ little money).

${ }^{8}$ Máxima da quantidade (devemos dizer apenas o que é necessário), máxima da qualidade (devemos dizer apenas o que é adequado e verdadeiro), máxima da relação/relevância (devemos dizer apenas o que é relevante) e máxima do modo (devemos ser claros e concisos). GRICE, H. P. "Lógica e conversação". In: DASCAL, M. (org.) Pragmática - problemas, críticas, perspectivas da linguística. Campinas: [s.ed.], 1982.

9 " [...] is not to convey any information contained in the text he is uttering but rather to create a special effect with the help of the text $[\ldots] "$
} 
FERREIRA - O humor na tradução para legendagem...

Vejamos, agora, os três tipos mais comuns de humor, segundo Raskin: o sexual, o étnico e o político. Vale lembrar que as fronteiras entre os tipos de humor podem se interpenetrar, no sentido de que uma piada étnica também pode ser política, ou sexual, e assim por diante.

\subsubsection{Humor sexual}

O primeiro tipo de humor classificado por Raskin é o sexual. A oposição de scripts — ou oposição scríptica - que prevalece aqui é normal / anormal, e as piadas deste tipo se dividem em quatro categorias, dependendo se são explicita ou implicitamente sexuais, e se fazem referência apenas a sexo em geral ou a um script sexual específico. Há scripts específicos relacionados ao TAMANHO DOS ÓRGÃOS GENITAIS, ao HOMOSSEXUALISMO, à INOCÊNCIA SEXUAL, dentre outros, todos abordados de forma estereotipada e exacerbada no humor. As categorias estabelecidas por Raskin (traduzidas livremente por mim) são as seguintes:

I. Piadas com oposição sexual / não-sexual implícita e não-específica: são implicitamente sexuais por não conterem nenhuma informação propriamente relacionada a sexo, apenas evocando um script sexual não específico.

II. Piadas com oposição sexual / não-sexual implícita e específica: da mesma forma que o tipo anterior, remetem a sexo de forma implícita, havendo a “sexualização dos referentes" (França, 2006: 177) sem que, de fato, se tenha falado sobre sexo. Mas, aqui, são evocados scripts específicos.

III. Piadas com oposição de natureza não-sexual no humor sexual explícito: seu tema é explicitamente sexual, mas seu movimento vai do sexual para o nãosexual, pois embora a mensagem seja sexual, o gatilho revela uma oposição de natureza não-sexual. Como o assunto é sexo, há necessariamente uma oposição sexual/não-sexual implícita, pois “(...) o simples fato de narrarmos uma situação explicitamente sexual evoca, automaticamente, o mundo não-sexual, 'normal', que se opõe ao conteúdo da piada" ${ }^{10}$ (Raskin, 1985: 160).

\footnotetext{
10 "[...] the very fact of describing an explicitly sexual situation evokes the "normal", non-sexual world automatically by opposing the content of the joke to it."
} 
FERREIRA - O humor na tradução para legendagem...

IV. Piadas com oposição de natureza sexual específica no humor sexual explícito: também passa uma mensagem sexual explícita, com uma oposição explícita e outra implícita. Mas, aqui, a graça reside na intensificação da oposição através de um script sexual específico.

\subsubsection{Humor Étnico}

Piadas étnicas se baseiam em scripts que refletem estereótipos internalizados por membros de uma cultura relativamente a membros de outras culturas. Esses estereótipos, ressalta Raskin (1985), não condizem com a realidade, ou condizem apenas com pequena parte dela, sempre exacerbada no humor. Além disso, o alvo das piadas nunca é a pessoa em si, mas o grupo sócio-cultural do qual ela faz parte, não se pensando o indivíduo, mas sim o coletivo.

As dicotomias que aqui prevalecem são possível / impossível e bom / ruim, sendo bons ou possíveis os valores da cultura à qual o falante pertence, e ruins ou impossíveis os valores do outro.

Raskin estabelece quatro principais categorias de scripts comumente associados às piadas étnicas: o das DISTORÇÕES LINGUÍSTICAS, o da PARVOÍCE, o da AVAREZA e o da ESPERTEZA. Além destes, há também os scripts não padronizados e o humor judaico.

I. Script das distorções linguísticas: esse é o script do suposto "falar errado", que pode refletir algumas distorções (fonéticas, sintáticas, morfológicas, etc) que o alvo, de fato, costume cometer, mas se fundamenta majoritariamente numa visão estereotipada do outro, refletindo a oposição binária e simplista do discurso bom / ruim. Esse script costuma vir associado ao da PARVOÍCE (a seguir), refletindo o preconceito de que falta inteligência a quem comete as distorções.

II. Script da parvoíce: nesse script também prevalece a oposição bom / ruim, sendo bons os valores do "eu", como a inteligência e a aptidão, e ruins, os do "outro", como a parvoíce e a inaptidão. A dicotomia superioridade / inferioridade também fica explícita, e julga-se inferior aquele que não 
FERREIRA - O humor na tradução para legendagem...

consegue entender aquilo que, para o grupo superior, é óbvio (Raskin, 1985). Praticamente todas as culturas do mundo fazem esse tipo de rotulação (estereotipada) em relação a outras culturas, tanto que, lembra Raskin, muitas piadas étnicas têm a mesma estrutura narrativa, mesmo em línguas diferentes como o clássico “Quantos [raça] são necessários para se trocar uma lâmpada?”.

III. Script da avareza: o script da AVAREZA é associado a grupos que cometam “todo tipo de ato estranho, irracional e até impossível para não ter que abrir mão do dinheiro ou de algum bem valioso" (Raskin, 1985: 189). ${ }^{11}$ Os judeus costumam ser associados a esse script.

IV. Script da esperteza: o script da ESPERTEZA é associado a grupos que cometam atos incomuns para atingirem seus objetivos, tentando se beneficiar de toda e qualquer situação. Pode vir associado ao script da AVAREZA.

V. Scripts específicos não padronizados: esses são scripts um pouco mais específicos, no sentido de que se voltam sempre para o mesmo alvo, independentemente de onde a piada se origine. Por exemplo, o script MINORIA ALTAMENTE SEXUALIZADA é comumente associado, de forma estereotipada, por quase todas as culturas do mundo, aos franceses, e o script RESPEITO PELAS TRADIÇÕES, aos ingleses.

VI. Humor judaico: segundo Raskin (1985), o humor judaico compõe uma categoria de humor étnico à parte porque judeus costumam ser alvo de seu próprio povo, não apenas de outras etnias. As piadas judaicas são moralmente aceitas na cultura judaica, mas somente membros dessa cultura podem gozar das brincadeiras sem serem vistos como preconceituosos. As piadas têm de envolver pelo menos um script especificamente judaico; é preciso que o resultado final da história seja como é exatamente porque se está falando de um judeu, não bastando que se faça referência a judeus. Para o escritor Moacyr Scliar, o grande diferencial do humor judaico é que "[há] nele uma fascinação com a lógica; mais precisamente pelo tênue limite que separa o racional do absurdo" (apud Lia, 2003: 44). Segundo Raskin (1985), alguns dos scripts compartilhados pela

\footnotetext{
11 "The stingy group will do anything weird, irrational and even impossible in order not to expend any money or other valuable commodity."
} 
FERREIRA - O humor na tradução para legendagem...

comunidade judaica são ESPERTEZA, INTELIGÊNCIA, AVAREZA, ANTISSEMITISMO, MÃE JUDIA e LÓGICA JUDAICA. Essa lógica, ressalta o autor, não é levada a sério nas piadas, que fazem rir exatamente porque ridicularizam a visão judaica extremamente racional da vida, que muitas vezes pode levar a situações absurdas.

Raskin cita ainda outras duas categorias: as piadas de superioridade nacional, que valorizam uma cultura, sem denegrir outra; e as piadas pseudo-étnicas, que parecem humor étnico, mas apresentam oposição de outra natureza.

\subsubsection{Humor Político}

Nas piadas políticas, segundo Raskin (1985), as oposições mais comuns são real / ideal e bom / ruim, refletindo a contradição entre o que as sociedades desejam de seus políticos e o que elas têm de fato. Como notou Freud (1905), o riso é uma válvula de escape psíquica, cuja função é liberar a energia agressiva que geralmente reprimimos diante de certas realidades.

A alusão, diz Raskin (1985), é um dos recursos linguísticos mais utilizados no humor político, o que pode tornar sua interpretação (e sua tradução) mais complexa, dado que emissor e receptor precisam compartilhar conhecimentos diretos e indiretos sobre o tema da piada. Por isso, a maioria das piadas políticas é compreensível apenas para pessoas que vivem determinado regime, em determinada época, ou conhecem determinado político.

Raskin (1985) divide as piadas políticas em dois grupos: as do primeiro buscam denegrir a imagem de um político, ou uma instituição, por exemplo; as do segundo buscam desmascarar, expor algum acontecimento que tenha sido ocultado durante algum governo. As fronteiras entre os dois grupos podem se interpenetrar. O autor enumera três tipos de piada do primeiro grupo e quatro, do segundo. Aqui, veremos apenas as principais características dos dois grupos.

I. Piadas que denigrem: podem se dirigir a um político, um partido, uma instituição, uma ideia, a um slogan político ou a uma sociedade. As mais populares são as que denigrem uma figura política e julgam se a figura é 
FERREIRA - O humor na tradução para legendagem...

adequada ou não (scripts bom / ruim, ideal / real) para ocupar o cargo que ocupa. Há certos pré-requisitos que as sociedades esperam de alguém que ocupe um cargo político e detenha tamanho poder em suas mãos: espera-se que seja competente, dedicado, culto, popular e, de preferência, um exemplo de moral e integridade. Muitos políticos, no entanto, não preenchem um ou nenhum desses pré-requisitos. Mas fique claro que os políticos não são atacados como pessoas, "mas sim como figuras públicas que supostamente não deveriam ter aquele(s) traço(s), mas sim o oposto dele(s) (Raskin, 1985: 226)". ${ }^{12}$

II. Piadas que expõem: podem expor os traços de uma nação (de forma semelhante às piadas étnicas), a falta de liberdade de expressão política, a escassez de itens essenciais às sociedades causada pelos regimes políticos, ou situações políticas específicas, como algum escândalo político que tenha sido camuflado pelas autoridades. As oposições, em geral, são também do tipo bom / ruim, ideal / real, sendo bom, ideal, que governos funcionem de forma clara e aberta em relação ao povo, e ruim, real, que governos escondam realidades comprometedoras (como uma possível natureza repressiva de seus regimes, por exemplo).

Agora, vejamos alguns aspectos sobre a legendagem e suas peculiaridades, que a distinguem de outros tipos de tradução.

\subsection{A legendagem}

A legendagem é uma prática de tradução audiovisual (TAV) com uma série de peculiaridades e restrições específicas, algumas das quais serão apresentadas a seguir. (Para maiores detalhes sobre a prática, ver Carvalho, 2005; Martinez, 2007; Diaz Cintas, 2007; Ferreira, 2010; dentre outros.)

Tecnicamente, pode-se definir a legendagem como a tradução dos diálogos falados em um programa audiovisual, em uma língua-fonte, para um texto escrito, em uma línguaalvo, apresentado em geral na parte inferior de uma tela, com o objetivo de reproduzir, em

\footnotetext{
12 " [...] as a public figure who is supposed not to have the alleged feature(s) and to have the exactly opposite feature(s)."
} 
FERREIRA - O humor na tradução para legendagem...

sincronia, esses diálogos, respeitando o espaço da tela e o tempo exato das falas. Uma de suas peculiaridades é o fato de ser uma tradução diagonal (Gottlieb, 1994), que faz a passagem do código oral ao escrito, gerando mudanças linguísticas, em relação ao original, que não ocorrem quando se traduz dentro do mesmo código. Uma das mudanças citadas por Gottlieb, por exemplo, é que no código oral o discurso é espontâneo e, portanto, permeado de marcadores conversacionais (hesitações, repetições, lapsos de linguagem, pausas, redundâncias etc.), os quais, em geral, são bastante reduzidos no código escrito (Martinez, 2007: 39). Outra peculiaridade da legendagem é que esta é um tipo de tradução subordinada (Diaz Cintas, 2007), pois o texto das legendas deve ser coerente com os outros códigos semióticos presentes em um programa audiovisual (as imagens e sons). Assim, a noção de "texto" deve ser expandida, até porque as legendas possuem um papel de apoio em relação ao original, e não de uma reprodução integral:

[a]s legendas não substituem o produto de origem e sequer o representam integralmente embora esta seja a expectativa mais comum por parte do público. (...) Elas não têm razão de existir sem o material original, tornando-se pouco compreensíveis sem o acompanhamento das imagens e dos sons correspondentes. (Carvalho, 2005: 97)

As três principais restrições técnicas que o tradutor de legendas costuma enfrentar estão associadas ao espaço, ao tempo e ao meio de exibição das legendas. O espaço é reduzido, podendo haver, no máximo, duas linhas, com cerca de 30 a 40 a caracteres, por legenda. O tempo de exibição deve respeitar o início e o fim das falas do original e o ritmo de leitura do espectador (no Brasil, de 15 caracteres por segundo). O meio de exibição das legendas (televisão, cinema, DVD, VHS etc.) também altera suas características, pois o número médio de caracteres por legenda varia de meio para meio, o que significa que um filme, quando exibido no cinema, terá uma tradução diferente de quando for exibido na televisão, ou em DVD.

As restrições linguísticas da tradução para legendas são inúmeras, mas aqui cito a questão dos sotaques, variações dialetais e gírias. O texto das legendas costuma sofrer uma "homogeneização" e a maioria dessas marcas costuma desaparecer, até porque é muito difícil transportar variações dialetais de uma língua falada para uma outra língua escrita. Qual seria, por exemplo, a tradução "equivalente" do iídiche, dialeto judaico falado em muitos filmes de Woody Allen? Qualquer tradução refletiria um grupo social diferente da 
FERREIRA - O humor na tradução para legendagem...

cultura-alvo, com no máximo algumas características em comum com o grupo da culturafonte. Em D. H., por exemplo, o personagem Harry, vivido por Allen, usa a expressão ofensiva meshuganah para se referir a uma ex-namorada, o que chamou atenção de uma jurada do festival de cinema de Veneza exatamente pela questão de sua "intraduzibilidade" para o italiano (Baxter, 1998). Nas traduções para o português analisadas, o termo foi traduzido por "louca" (cinema) e "vigarista" (VHS), ambos sentidos dicionarizados, mas que não refletem o dialeto específico do original. Como ressalta Chiaro (2009: 158), "transcrever as legendas de um filme inteiro em qualquer variedade linguística que não a padrão seria um caso inédito". ${ }^{13}$

Quanto às restrições pragmáticas, ressalto aqui duas: os já citados marcadores conversacionais, que costumam desaparecer das legendas, dado seu baixo valor semântico; e a linguagem ofensiva, ou obscena, que também pode ser omitida, ou, pelo menos, amenizada, devido a alguma norma, imposta por clientes ou produtoras (dentre outros), que obrigue os tradutores a tomarem tal medida, principalmente dependendo do público-alvo e do horário em que o material for exibido.

Quanto às restrições culturais, tratarei aqui da que mais chamou atenção no caso do filme analisado: a tradução de referentes culturais específicos da cultura-fonte, como nomes de lugares, comidas ou bebidas típicas, feriados ou instituições locais, unidades de medida, livros, filmes, personalidades, entre outros (Chiaro, 2009). Apenas para situar o leitor, nos diálogos de D.H. foi identificado um total de 58 referentes culturais diferentes.

O que acontece é que esses referentes são elementos específicos da cultura-fonte, e não são necessariamente conhecidos na cultura-alvo, onde a tradução é veiculada. E o não reconhecimento de um referente pode atrapalhar a fluência de leitura das legendas, o que não é desejável. Por essa razão, diversos teóricos já sugeriram estratégias para o tratamento de referentes culturais na legendagem (ver Pedersen, 2007; Martinez, 2007; Carvalho, 2005; dentre outros). Uma das estratégias, por exemplo, é a conservação do referente como consta no original, independentemente de ser mais ou menos conhecido na cultura-alvo, optando-se por uma estrangeirização da tradução; outra é a substituição do referente por referentes semelhantes e conhecidos na cultura-alvo, optando-se pela domesticação da

13 " [...] transcribing the subtitles of an entire film in any variety other than the Standard would be unprecedented." 
FERREIRA - O humor na tradução para legendagem...

tradução; pode-se também generalizar o referente, ou, ainda, especificá-lo (ambas também estratégias de domesticação). No caso da primeira estratégia, uma marca de sabão em pó estrangeira $X$, citada no original, será mantida na tradução; na segunda, será substituída por uma marca de sabão em pó nacional $Y$; na terceira, será traduzida como sabão em pó, a designação genérica do produtor; e, na quarta, será traduzida como sabão em pó X, mantendo-se a marca estrangeira, mas informando o tipo de produto se está falando.

Chiaro (2009) ressalta que a questão dos referentes culturais, na legendagem, tem um grande diferencial: o público tem acesso não apenas ao texto escrito, a legenda, mas também a informações visuais e sonoras, com as quais o tradutor deve ser coerente. Se a imagem do referente for apresentada na tela, por exemplo, dificilmente o tradutor poderá recorrer à substituição do mesmo, ainda que este não seja facilmente reconhecido pelo espectador. Jan Pedersen (2007) levanta outra questão relevante, o fato de que, caso um referente cultural seja substituído por outro análogo da cultura-alvo, o público pode perceber a discrepância entre a realidade estrangeira do filme e a referência nacional, e pode passar a dividir sua atenção entre assistir ao filme e buscar outros "erros" na tradução. No entanto, quando os referentes culturais funcionam como gatilhos das piadas, Chiaro (1992) e Pedersen (2007) lembram que a busca por uma verdadeira equivalência entre original e tradução pode levar a uma não-piada, caso os mesmos não sejam reconhecidos na cultura-alvo — o importante é manter o gatilho, seja mantendo-se ou não o referente, conforme este seja mais ou menos conhecido na cultura-alvo.

Há, no entanto, quem seja totalmente contra a domesticação de referentes culturais em nome do humor. O pesquisador John Stone, da Universidade de Barcelona, e a tradutora Rosa Roig afirmam que domesticar referentes na TAV é ser condescendente com o público-alvo, nivelando sua inteligência por baixo. O que Stone e Roig (2001) alegam é que o tradutor, ao fazer esse tipo de modificação, está não apenas supondo que falte ao público conhecimento suficiente para decifrar a piada, mas também descaracterizando o texto original. Além disso, enfatizam, devemos supor que o público que se disponha a assistir a um filme estrangeiro esteja minimamente disposto a tolerar informações pouco conhecidas, sem que isso seja um desestímulo.

Concordo com o teórico Diaz Cintas (2007: 148), para quem fundamental é haver um equilíbrio entre "o esforço que o espectador faz para processar um item e sua relevância 
FERREIRA - O humor na tradução para legendagem...

para o entendimento da narrativa do filme (...)"14. Para poder fazer essa avaliação, o tradutor deve assistir ao filme inteiro antes de começar a tradução.

Veremos um exemplo mais à frente de piada com referente cultural específico.

\section{Análise do corpus}

Vejamos, agora, a análise das sequências de humor selecionadas no filme Desconstruindo Harry e de suas respectivas traduções para legendas, feita à luz da teoria semântica de Raskin (1985). Seis exemplos serão apresentados no presente trabalho.

A análise transcorreu da seguinte forma: primeiramente, as situações cômicas do filme foram identificadas e classificadas de acordo com os três tipos de humor relacionados por Raskin (1985): o sexual, o étnico e o político. Em seguida, foram examinadas as oposições scrípticas evocadas nas situações, com seus respectivos gatilhos. Por fim, foi examinado o tratamento dado às situações nas duas traduções analisadas (cinema e VHS). Para a análise das soluções tradutórias, foi elaborado um quadro de estratégias, pensadas a partir dos possíveis recursos disponíveis ao tradutor. O quadro se baseou no trabalho de Martins (2009) ${ }^{15}$, sendo que, aqui, serão apresentadas apenas as estratégias identificadas nos exemplos apresentados. São elas:

1. Manutencão: a tradução é literal e mantém a mesma oposição scríptica do original.

2. Recriação: a tradução mantém oposição scríptica igual ou muito semelhante à do original, mas através de um recurso linguístico ou de um script diferente na tradução e, não, de uma tradução literal.

3. Explicitacão: a tradução explicita um dos scripts do original.

4. Neutralizacão: a tradução mantém apenas um dos scripts do original.

5. Omissão: a tradução omite integralmente a oposição de scripts do original.

\footnotetext{
14 “ $[\ldots]$ the effort required by the viewer to process an item, and its relevance for the understanting of the film narrative $[\ldots]$ "..

${ }^{15}$ MARTINS, M. A. P. A tradução dos jogos de palavras shakespearianos: o caso de A megera domada. In: CAMATI, A. S.; MIRANDA, C. A. (Orgs.) Shakespeare sob múltiplos olhares. 1 $1^{\text {a }}$ ed., v. 1: $317-345$. Curitiba: Solar do Rosário, 2009.
} 
FERREIRA - O humor na tradução para legendagem...

Cabe ressaltar que as "estratégias tradutórias" não existem a priori, isto é, não foram criadas e adotadas deliberadamente pelos próprios tradutores e, sim, propostas para fins da análise do corpus, com base nos efeitos aqui identificados.

Também vale lembrar que o humor é relativo: "não há um enunciado humorístico em si” (Rosas, 2002: 42). A graça de um enunciado depende de uma série de conhecimentos compartilhados, direta e indiretamente, pelo emissor e pelo receptor do mesmo, bem como de não haver um envolvimento emocional entre o receptor da piada e o tema abordado (Bergson, 1900) - basta pensar em uma piada étnica: contada para o grupoalvo, certamente ela não surtirá o efeito esperado. O contexto também influencia: todos nós corremos o risco de fazer um comentário potencialmente engraçado no lugar errado, gerando um enorme desconforto (Chiaro, 1992). Por essas (e outras) razões, determinadas sequências de D.H. podem não ser reconhecidas como cômicas pelo leitor, independentemente do que pretendeu originalmente Woody Allen (da mesma forma que sequências que não são intencionalmente cômicas, no filme, poderiam ser interpretadas como tal). Todas, no entanto, apresentam aquilo que, para Raskin (1985), é fundamental em um texto humorístico: sobreposição e oposição de scripts semânticos e um (ou mais) gatilho(s).

Vejamos, a seguir, os exemplos, a começar pelos de humor sexual.

\subsection{Humor sexual}

\section{Exemplo 1 - Piada sexual com duplo sentido}

Cena: Leslie tem um caso com Ken, o marido de sua irmã. Os dois estão transando na sala da casa de campo da família de Leslie, escondidos do resto da família, que se encontra no quintal. É aí que começa o diálogo. De repente, a avó de Leslie entra na sala e o casal é surpreendido, mas, após o susto inicial, continua transando e conversando com a senhora. Em determinado momento, o público percebe que a avó de Leslie é cega.

Personagens:

Leslie - (L)

Ken - $(\mathrm{K})$

Avó de Leslie - (A)

\begin{tabular}{|l|l|}
\hline \multicolumn{1}{|c|}{ Tradução cinema } & \multicolumn{1}{c|}{ Tradução VHS } \\
\hline (L:) Já gozei. & Terminei. \\
(L:) - Já pode gozar. & - Goze quando quiser. \\
\hline
\end{tabular}




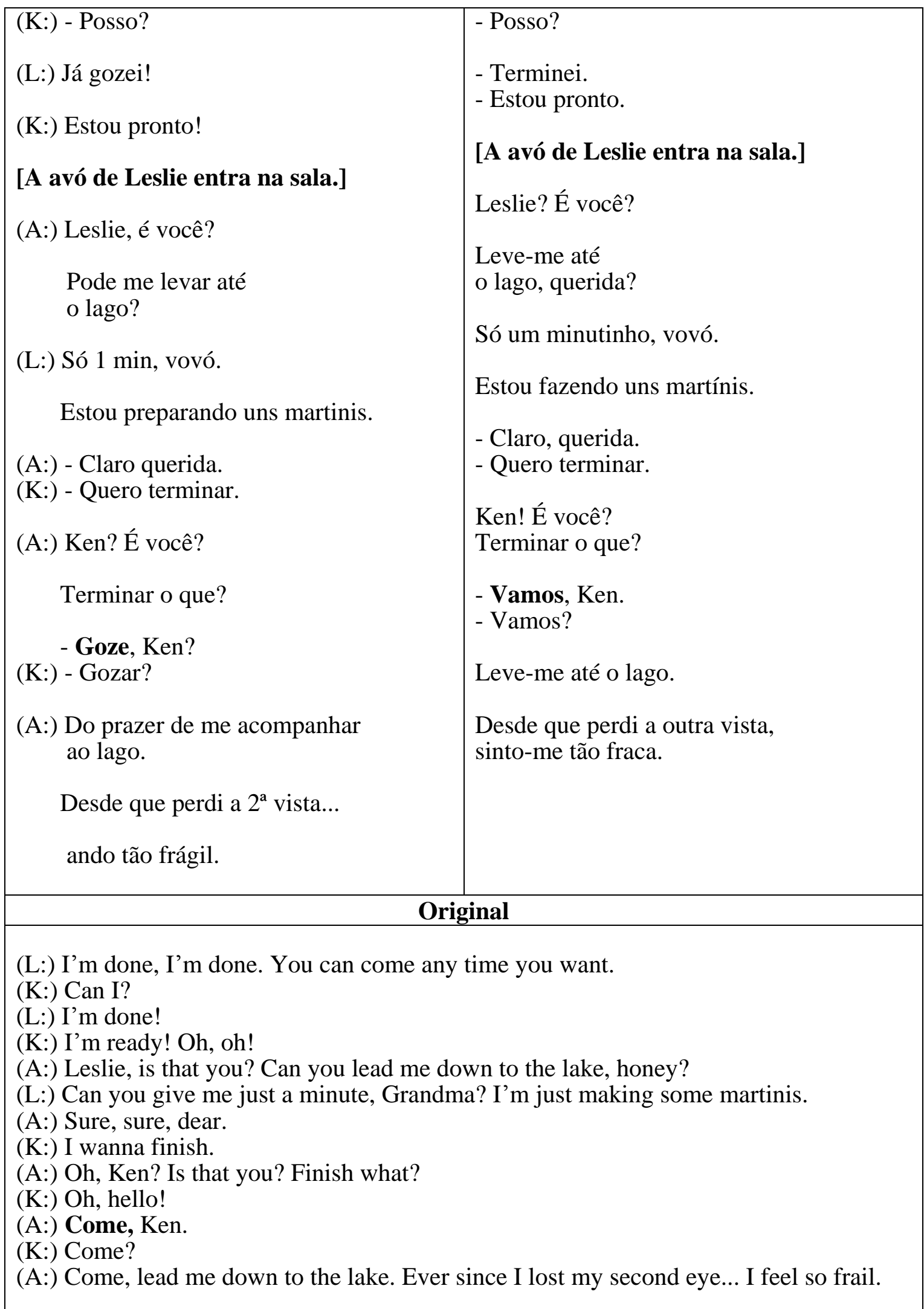


FERREIRA - O humor na tradução para legendagem...

No exemplo acima, o código visual tem tanta importância quanto o verbal na construção do humor, pois, além do gatilho verbal (que será analisado), há também um “gatilho visual”, que é detonado quando o público percebe que a avó de Leslie é cega. É a partir daí que a cena relativamente tensa, de um casal adúltero sendo pego em flagrante, torna-se cômica. Essa informação não fica clara a partir de uma simples leitura das legendas, o que só comprova a afirmação de Carvalho (2005) de que as legendas cumprem um papel de apoio e não de uma reprodução integral do original.

Quanto à construção verbal do humor, seguindo a classificação de Raskin (1985), a piada é do tipo sexual, com uma oposição sexual / não-sexual implícita e não-específica. É implícita porque, embora a cena seja visualmente explícita para o público, o gatilho não o é, e é nele que nos concentramos. É não-específica porque o evoca apenas a ideia de sexo em geral (em oposicao a uma piada especifica, que se refira a homossexualidade, tamanha dos orgaos genitais etc.

O gatilho ambíguo come evoca a oposição dos scripts CONVITE e ESTÍMULO. Come pode significar tanto "vir, se aproximar" quanto "atingir o orgasmo" ("to advance towards the speaker or towards a specified place; approach", "to experience orgasm". Fonte: American Heritage Dictionary of the English Language). No exemplo, o termo foi empregado com duplo sentido e ambos os sentidos, o sexual e o não-sexual, são dicionarizados na língua inglesa. Este é o grande diferencial do duplo sentido: permitir um jogo de palavras em que não é preciso manipular nenhum termo do léxico, bastando apenas inseri-lo no contexto certo para que a leitura ambígua seja possível (Chiaro, 1992).

A oposição scríptica básica é do tipo normal / anormal, podendo ser considerado normal que a avó de Leslie convide Ken para passear com ela e anormal que o estimule a concluir o ato sexual.

No português do Brasil, no entanto, não há um verbo que permita o exato jogo de palavras evocado por come no inglês. Foi necessário, portanto, que ambos os tradutores realizassem algum tipo de mudança. Na tradução para o cinema, foi empregado o verbo “gozar”, que mantém a oposição scríptica sexual / não-sexual, já que possui conotação sexual (“atingir o clímax”) e não-sexual (“aproveitar”, “deleitar”) dicionarizadas no Brasil, com uma mudança em relação à conotação não-sexual do original. Já na tradução para VHS, com a forma verbal "vamos", não foi mantida a oposição scríptica, pois o verbo não 
FERREIRA - O humor na tradução para legendagem...

possui conotação sexual dicionarizada. Poderíamos até interpretá-lo como uma interjeição feita pela avó de Leslie, como se apressasse Ken para atingir o clímax, mas, para isso, caberia uma exclamação ao fim da frase, não um ponto final, o que não é o caso.

A partir desses dados, podemos concluir que a estratégia tradutória adotada no cinema foi a de recriação, pois a tradutora manteve a oposição scríptica evocada no original recriando um dos scripts envolvidos, enquanto que, no VHS, a estratégia foi a de neutralização, pois o script sexual sofreu um apagamento.

\section{Exemplo 2 - Piada sexual com palavrão}

Cena: Harry vai atrás de sua ex-mulher, Joan, que o vem ignorando há algum tempo. Ele consegue encontrá-la na rua e pede a ela que pare para conversar com ele, mas ela, mais uma vez, o rejeita. Ele insiste, pois quer convencê-la de que seria bom ele levar o filho do casal, Hilly, na viagem que fará até sua antiga universidade, onde será homenageado.

Personagens:

Harry - $(\mathrm{H})$

Joan - (J)

\begin{tabular}{|c|}
\hline Tradução cinema \\
\hline $\begin{array}{c}\text { (H:) Será bom pra ele me ver } \\
\text { homenageado. }\end{array}$
\end{tabular}

(J:) Não quero que ele o veja pelo resto da sua vida!

(H:) Será um dia no campo. Quer parar?

Um dia no campo é tão ruim?

(J:) Ele tem 9 anos...

e onde aprendeu a dizer "comer xoxota" e "Deus que se foda"?

(H:) Acha que foi comigo?

(J:) Tenho cara de imbecil?

\section{Tradução VHS}

Troco um dia. Ele verá

o pai ser homenageado.

Não quero que ele te veja

pro resto da vida.

Passará um dia no campo.

Pare um segundo?

Passará um dia no campo.

É tão ruim?

Ele tem nove anos.

Onde aprende coisas como:

"castor trepador"

e "Deus que se dane"?

- Comigo?

- Tenho cara de imbecil?

\section{Original}

(H:) We'll trade one day. It'll be good to see... the kid will see his father honored, it's nice.

(J:) I don't want him to see you. I don't want him to see you for the rest of your life! 
FERREIRA - O humor na tradução para legendagem...

(H:) He'll have a day in the country. Will you stop one second? The kid will have a day in the country. What is so bad?

$(\mathrm{J}:)$ He is 9 years old. Where does he learn phrases like "banging beaver" and "fuck God"?

(H:) What are you saying? From me?

(J:) Oh, what do I look like, an imbecile?

O exemplo acima é uma piada com oposição sexual específica no humor sexual explícito. Os gatilhos banging beaver e fuck God são do tipo contraditório e remetem a duas oposições scrípticas, uma implícita e outra explícita. A oposição implícita é evocada pelo simples uso da linguagem obscena, que evoca automaticamente o script sexual, anormal, em oposição ao universo não-sexual, normal. A oposição explícita, também do tipo sexual / não-sexual, normal / anormal, evoca o script específico IGNORÂNCIA SEXUAL (que reforça o caráter "anormal” do script sexual). Esse é um script comumente associado a crianças e clérigos, podendo ser considerado normal que crianças, como a do filme, não utilizem linguagem obscena e ofensiva e anormal que a utilizem.

A expressão fuck God não apresenta problemas de tradução, já que há expressões igualmente ofensivas em português. O único problema poderia ser uma possível censura imposta aos tradutores por parte de seus contratantes ou clientes. Já a expressão banging beaver não é empregada no sentido literal: ambos os termos da expressão poderiam ser interpretados sexualmente ou não, visto que to bang pode significar "bater" ou "ter relação sexual” e beaver pode significar "castor" ou "genitália feminina" (numa acepção grosseira); no entanto, não resta dúvida de que ambos os termos foram empregados com conotação sexual - por que outra razão Joan ficaria tão furiosa?

A tradução para o cinema, com os gatilhos, "comer xoxota" e "Deus que se foda", mantém a linguagem de baixo calão do original. Assim, a tradutora optou pela estratégia de manutenção, de forma que a oposição scríptica original foi preservada.

Quanto à tradução para VHS, dois pontos chamam atenção: as expressões chulas foram amenizadas e há um erro de tradução. No caso de "Deus que se dane", houve amenização do gatilho original, mas podemos considerar que tenha sido mantido o script sexual ("Danar: causar ou passar por depravação, degeneração; corromper; perverter"; fonte: Dicionário Aulete Digital). Assim, a oposição sexual específica, evocada pelo script específico INOCÊNCIA SEXUAL foi mantida, mas não a oposição evocada 
FERREIRA - O humor na tradução para legendagem...

implicitamente pelo uso de linguagem obscena, pois "danar" não chega a ser um termo obsceno. Considero, assim, que a estratégia tradutória foi a de neutralização (de uma das oposições). Já no caso de "castor trepador", considero ter havido omissão da oposição scríptica do original, pois, no contexto da cena, o termo beaver não se refere a "castor", podendo este ser considerado um erro do tradutor, principalmente porque, no diálogo, o termo não faz sentido. Assim, mesmo que "trepador" mantenha a conotação sexual, a expressão como um todo perdeu o sentido.

\section{Exemplo 3 - Piada sexual com referente cultural}

Cena: É dia de visita dos pais no colégio onde estuda Hilly, filho de Harry. Pai e filho estão sentados em uma mesa redonda, junto a outras crianças, também acompanhadas de seus pais ou mães. Harry conversa com Hilly, e a mãe de outra criança, sentada na mesa ao lado, fica atenta à conversa e parece chocada com o que ouve. Harry está dando alguns conselhos ao filho:

Personagens:

Harry - (H)

Hilly - (Hi)

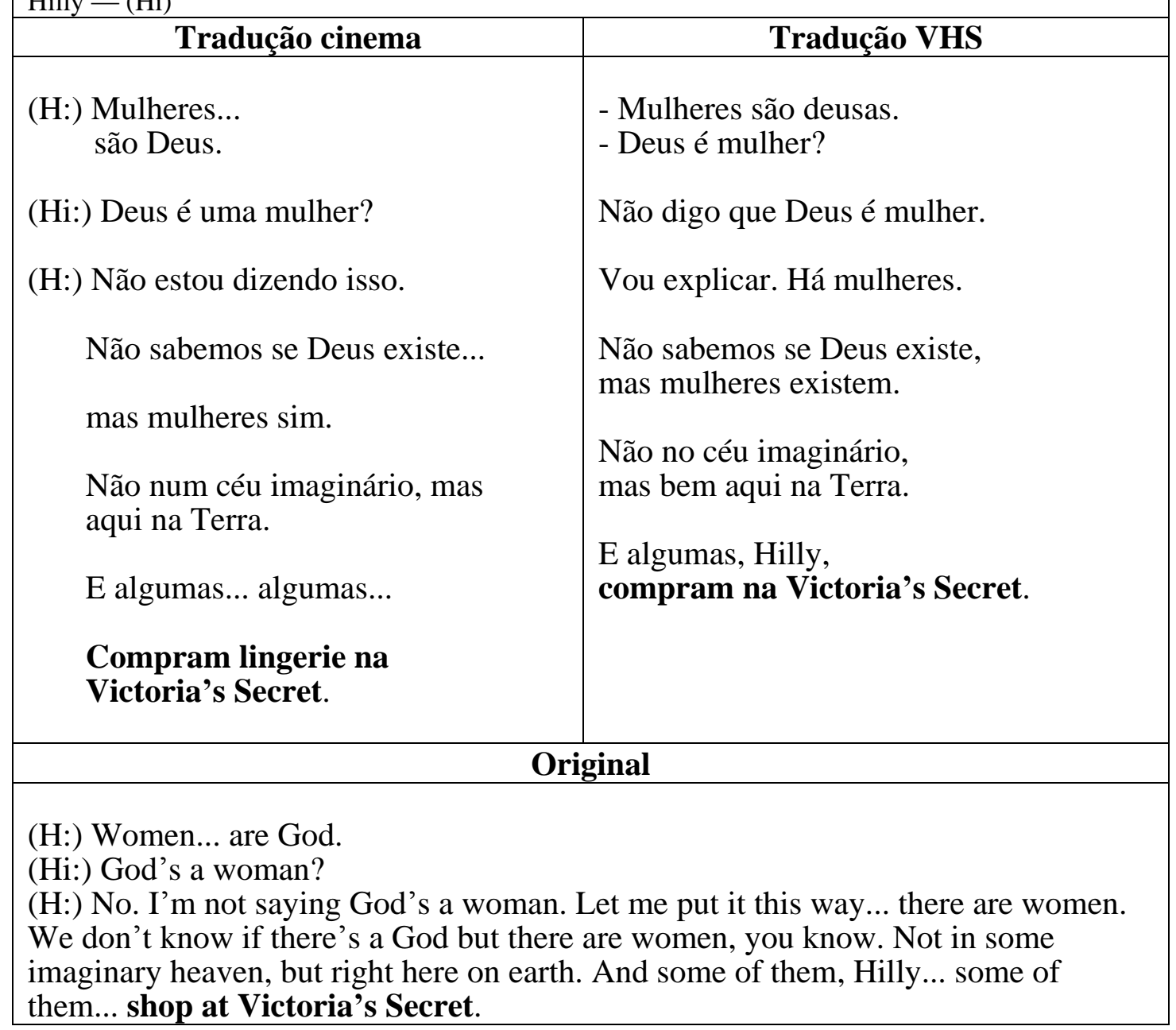


FERREIRA - O humor na tradução para legendagem...

No exemplo acima, o gatilho shop at Victoria's Secret é do tipo que revela uma contradição; além disso, cita um referente específico da cultura norte-americana. Como já mencionado, Woody Allen costuma citar referentes culturais em seus filmes, inclusive em sequências em que estes funcionam como gatilhos. No exemplo acima, o tratamento dado ao referente foi diferente nas duas traduções: no cinema, foi especificado, através da adição da informação lingerie; no VHS, foi conservado como consta no original.

A piada evoca uma oposição sexual / não-sexual implícita e específica. Implícita porque nenhuma informação de natureza explicitamente sexual é mencionada, sexual é apenas o script evocado (a marca Victoria's Secret é famosa por vender lingeries sensuais); específica porque evoca o script específico IGNORÂNCIA SEXUAL, associado a crianças, como Hilly.

Como na tradução para o cinema foi adicionada uma informação sobre o referente, a oposição scríptica implícita do original passou a ser explicitamente sexual, já que, enquanto no original o referente precisa ser reconhecido para que a piada tenha graça, na tradução, a palavra "lingerie" evoca explicitamente o script sexual, independentemente de o referente ser reconhecido ou não. A tradutora, portanto, optou pela estratégia tradutória de

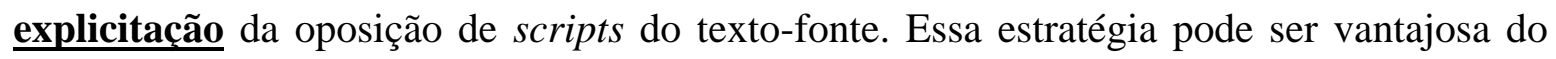
ponto de vista do timing do humor, pois torna a mensagem mais direta. É fato que o humor costuma ter um ritmo próprio, em geral rápido, e não é difícil perceber que, quando o emissor perde esse ritmo, dificilmente conquista os ouvintes — o próprio Woody Allen declarou que "não importa a rapidez com que a cena é rodada, você sempre vai querê-la mais rápida ainda na comédia. Esta é uma regra de ouro” (Björkman, 1993: 52). Dessa forma, se a explicitação do referente possibilitar que o receptor capte a natureza sexual do exemplo mais rapidamente, a estratégia pode ser vantajosa. No entanto, a explicitação também pode ser considerada uma estratégia de apagamento ${ }^{16}$, porque faz desaparecer o efeito retórico do original, "na medida em que introduz uma espécie de glosa intratextual que busca preservar os dois (ou mais) sentidos contemplados, em detrimento da equivalência estilística" (Martins, 2009: 4). Nesse sentido, pode não ser considerada uma estratégia vantajosa.

\footnotetext{
${ }^{16}$ Assim como a neutralização.
} 
FERREIRA - O humor na tradução para legendagem...

Na tradução para VHS foi adotada a estratégia de manutencão da oposição scríptica implícita do texto-fonte. Essa opção favorece aqueles da cultura-alvo que conhecem o referente, pois mantém o script do original e a equivalência estilística.

\subsection{Humor étnico}

Exemplo 4 - Piada com script étnico específico e não-padronizado

Cena: Harry resolve fazer uma visita a sua irmã, Doris, a quem não via há alguns anos. Os dois se retiram para conversar e começam a discutir a religiosidade de Doris, e a falta de religiosidade de Harry.

Personagens:

Harry - (H)

Doris - (D)

\begin{tabular}{|c|c|}
\hline Tradução cinema & Tradução VHS \\
\hline $\begin{array}{l}\text { (D:) porque sempre o irritou minha } \\
\text { volta às minha raízes. } \\
\text { (H:) Raízes? V. era uma menina } \\
\text { doce e gentil... } \\
\text { e me fez sobreviver à minha } \\
\text { infância. } \\
\text { Aí foi para Ft. Lauderdale... } \\
\text { e conheceu esse fanático } \\
\text { obcecado... } \\
\text { que a entope de superstições. } \\
\text { (D:) É tradição. } \\
\text { (H:) Tradição é a ilusão } \\
\text { da permanência. } \\
\text { (D:) V. não tem valores. Sua vida... } \\
\text { é niilismo, cinismo, sarcasmo } \\
\text { e orgasmo. } \\
\text { (H:) Na França, esse slogan me } \\
\text { elegeria. }\end{array}$ & $\begin{array}{l}\text { Você se enfurece } \\
\text { porque voltei às minhas raízes. } \\
\text { Que raízes? } \\
\text { Era uma menina maravilhosa. } \\
\text { Você me ajudou } \\
\text { durante a infância. } \\
\text { Depois se mudou para Fort Lauderdale, } \\
\text { conheceu este fanático, } \\
\text { e ele te encheu de superstição. } \\
\text { - É tradição. } \\
\text { - Isso é ilusão de permanência. } \\
\text { Você não tem valores. Sua vida é } \\
\text { niilismo, cinismo, sarcasmo e orgasmo. } \\
\text { Na França, eu ganharia } \\
\text { com esse slogan. }\end{array}$ \\
\hline \multicolumn{2}{|c|}{ Original } \\
\hline
\end{tabular}


FERREIRA - O humor na tradução para legendagem...

childhood. And, and, and, you know... Then you go away to Fort Lauderdale, and you meet this fanatic, this zealot. And, and... he fills you full of superstition.

(D:) It's tradition.

(H:) Tradition is the illusion of permanence.

(D:) You have no values. Your whole life it's nihilism, cynicism, sarcasm and orgasm.

(H:) You know, in France I could run on that slogan and win.

O exemplo acima, além de ser uma piada étnica, é também sexual e, indiretamente, política. Há, nele, dois gatilhos, ambos do tipo contraditório. O primeiro é orgasm, cujo sufixo -asm mantém semelhança fonético-morfológica com os três sufixos citados anteriormente (-ism, -ism, -asm), havendo aí uma reiteração de sons. No entanto, quanto a seu valor semântico, orgasm difere completamente dos três outros termos mencionados, pois remete a uma reação fisiológica, uma experiência corpórea, enquanto que nihilism, cynicism e sarcasm são da ordem do saber, do universo racional.

Assim, podemos enquadrar o exemplo na categoria de piadas com oposição específica no humor sexual explícito, sendo explícito porque o termo orgasm remete a sexo e específico porque o script PROMÍSCUO é evocado. A primeira oposição scríptica é, portanto, sexual / não-sexual e reflete a dicotomia normal / anormal, podendo ser considerado normal que os valores de Harry sejam baseados em campos do saber e anormal que se baseiem em experiências mundanas.

O segundo gatilho é o comentário de Harry - You know, in France I could run on that slogan and win - que evoca o script étnico específico e não-padronizado MINORIA ALTAMENTE SEXUALIZADA, associado por diversas culturas do mundo aos franceses. A oposição que prevalece é da ordem do possível / impossível sendo possível, na cultura do "outro", inserir sexo em um slogan político e impossível, na cultura do "eu”, inseri-lo.

Nas duas traduções foi adotada a estratégia tradutória de manutencão dos dois gatilhos e oposições, preservando-se tanto a reiteração de sons, quanto o estereótipo sobre os franceses, que também vigora no contexto brasileiro.

\section{Exemplo 5 - Piada judaica}

Cena: Doris (irmã de Harry), Burt (marido de Doris) e Harry — todos de origem judaica — estão discutindo. Doris e Burt criticam Harry, alegando que ele não só não possui religiosidade, como também é anti-semita, pois retrata os judeus de forma negativa em seus livros. 
FERREIRA - O humor na tradução para legendagem...

\begin{tabular}{|c|c|}
\hline $\begin{array}{l}\text { Personagens: } \\
\text { Harry - (H) } \\
\text { Doris - (D) } \\
\text { Burt - (B) }\end{array}$ & \\
\hline Tradução cinema & Tradução VHS \\
\hline $\begin{array}{l}\text { (D:) Ele não tem espírito. Só pensa } \\
\text { em física e em xoxota. } \\
\text { Desculpe a expressão. } \\
\text { Se tiver câncer, irá direto à } \\
\text { sinagoga de yarmulke. } \\
\text { (H:) Câncer? Eu como brócolis. } \\
\text { (B:) Importa-se com o Holocausto ou } \\
\text { acha que nunca aconteceu? } \\
\text { (H:) Não só sei que perdemos } \\
6 \text { milhões... } \\
\text { mas o pior é que recordes existem } \\
\text { para serem quebrados. }\end{array}$ & $\begin{array}{l}\text { Não tem espírito. Aposta tudo } \\
\text { na física e nas xoxotas. } \\
\text { Perdoem o linguajar. } \\
\text { Quando tiver câncer, } \\
\text { aparecerá na sinagoga } \\
\text { na fileira da frente } \\
\text { usando solidéu. } \\
\text { Por que terei câncer? } \\
\text { Como brócolis. Faço tudo direito. } \\
\text { Sente pelo Holocausto? } \\
\text { Ou acha que nunca aconteceu? } \\
\text { Não só sei que perdemos } \\
\text { seis milhões, } \\
\text { mas o pior é que } \\
\text { os registros são violados. }\end{array}$ \\
\hline & \\
\hline $\begin{array}{l}\text { you'll excuse the expression... Yeah, wa } \\
\text { synagogue sitting in the front row in a y } \\
\text { (H:) Why should I get cancer? I eat broc } \\
\text { (B:) You care even about the Holocaust } \\
\text { (H:) Not only do I know that we lost } \\
\text { are made to be broken. }\end{array}$ & $\begin{array}{l}\text { verything on physics and pussy. Well, if } \\
\text { he gets cancer, he'll be the first one in the } \\
\text { lke. } \\
\text { I do everything right. } \\
\text { lo you think it never happened? } \\
\text { lion, but the scary thing is that records }\end{array}$ \\
\hline
\end{tabular}

Sobre o exemplo acima, dois pontos podem ser levantados. O primeiro é que é uma piada judaica porque evoca o script LÓGICA JUDAICA, que remete à ideia de que judeus são tão fascinados pelo raciocínio lógico que, às vezes, chegam a conclusões inesperadas, caso do comentário de Harry. O gatilho Not only do I know that we lost 6 million, but the scary thing is that records are made to be broken é, portanto, contraditório. O segundo ponto é que o gatilho também é ambíguo, pois o termo records pode remeter a dois campos 
FERREIRA - O humor na tradução para legendagem...

semânticos diferentes, o de "registro de fatos" e o de "melhor desempenho em uma disputa" ("An account, as of information or facts, set down especially in writing as a means of preserving knowledge; The best performance known, as in sport"; fonte: American Heritage Dictionary of the English Language). Quando Burt menciona o Holocausto a Harry, imagina-se que este terá a sensibilidade de reconhecer que a tragédia de fato aconteceu, é um "fato registrado". No entanto, ele emprega, a seguir, a conotação positiva de "melhor desempenho".

A oposição scríptica evocada pelo gatilho é do tipo normal / anormal, sendo normal que Harry tenha a sensibilidade de reconhecer a seriedade da conversa com Burt e anormal que sua lógica desvie o assunto a ponto de sua conversa perder o sentido inicial.

No português do Brasil, não há um termo que possua ambas as acepções do original. $\mathrm{Na}$ tradução para o cinema, o termo "recordes" não mantém o duplo sentido do original, mas mantém a ideia de expansão da lógica ao absurdo, já que, como vimos, essa é uma conotação positiva do termo. A estratégia da tradutora, portanto, foi a de neutralização do duplo sentido (mas manutenção do script LÓGICA JUDAICA). Já na tradução para VHS, o termo foi traduzido por "registros", o que não está linguisticamente incorreto, mas que considero uma estratégia de omissão, pois transformou a piada em uma não-piada (até porque o termo "broken" foi erroneamente traduzido por "violados"). É preciso lembrar que estamos pensando as estratégias em relação ao tratamento dos scripts semânticos do original e, por isso, embora, em sentido estrito, o termo "registro" mantenha uma das acepções do original (o que poderia ser considerado uma estratégia de neutralizacão), o fato de ter-se mantido a acepção não garante a manutenção do script original, LÓGICA JUDAICA. A frase "mas o pior é que os registros são violados" não mantém o duplo sentido e também não é absurda, sendo apenas uma constatação literal.

Vale dizer, por fim, que o humor de Woody Allen não pode ser classificado como judaico, pois, pelo contrário, muitas vezes ele tenta se afastar desse estereótipo. No entanto, segundo a lógica de Raskin (1985), essa não deixa de ser uma piada judaica.

\subsection{Humor político}

Exemplo 6 - Piada política e sexual com alusão

Cena: Harry Block está falando a seu analista sobre o fato de que sua vida não mudou desde a juventude, 
FERREIRA - O humor na tradução para legendagem...

pois ele ainda tem vontade de transar com todas as mulheres que vê pelo caminho.

Todas as falas são de Harry.

\begin{tabular}{|c|c|}
\hline Tradução cinema & Tradução VHS \\
\hline $\begin{array}{l}\text { Não sei o que há comigo. } \\
\text { Não amadureci e sinto... } \\
\text { Vejo homens da minha idade... } \\
\text { Penso em trepar com todas } \\
\text { que conheço. } \\
\text { Vejo uma mulher no banco... } \\
\text { ou no ônibus... } \\
\text { e penso: “Como ela é nua? } \\
\text { Posso trepar com ela?" } \\
\text { É loucura. } \\
\text { Vejo advogados e médicos } \\
\text { que conheço... } \\
\text { com famílias e casas. } \\
\text { Não são tão... } \\
\text { O presidente dos EUA pensa em } \\
\text { trepar com todas que conhece? } \\
\text { Mau exemplo. }\end{array}$ & $\begin{array}{l}\text { Não sei o que } \\
\text { acontece comigo. } \\
\text { Sabe, ainda não amadureci } \\
\text { e sinto que, não é-- } \\
\text { Vejo os outros da minha idade. } \\
\text { Vivo pensando em comer } \\
\text { toda mulher que conheço. } \\
\text { Vejo uma, no banco, } \\
\text { uma estranha, no ônibus-- } \\
\text { Penso: “Como será que ela } \\
\text { fica pelada? Poderíamos dar uma?" } \\
\text { Isso é loucura. } \\
\text { Vejo amigos } \\
\text { advogados e médicos. } \\
\text { Têm famílias e casa. } \\
\text { E não são tão-- } \\
\text { O presidente dos Estados Unidos } \\
\text { quer comer todas? Talvez. } \\
\text { Bem, então. Mau exemplo. }\end{array}$ \\
\hline
\end{tabular}

\section{Original}

(H:) I don't know what's been happening to me. You know, I, you know, you know, I just have not grown up and I feel, you know... It's not... You know, I see other guys my age. I mean, I'm always thinking of fucking every woman I meet. I meet a woman, whoever, in the bank, a stranger, I see a woman on the bus, I think: What's she look like naked? Is it possible I can fuck her? This is crazy. I, I, I see guys I know that are lawyers and doctors, they have families and houses. They're not so, you know... Does the President of the United States wanna fuck every woman he meets? You know, so... Bad example. 
FERREIRA - O humor na tradução para legendagem...

O exemplo acima é uma piada que denigre uma figura política e o mecanismo linguístico utilizado foi uma alusão, um dos mecanismos mais comuns no humor político, de acordo com Raskin (1985). Pode-se dizer também que a piada expõe uma situação, dado que a alusão remete a um escândalo político específico (o envolvimento sexual do expresidente norte-americano Bill Clinton com uma de suas estagiárias).

O gatilho Bad example revela uma contradição. A pergunta de Harry - Does the President of the United States wanna fuck every woman he meets? - é potencialmente retórica, isto é, ao fazer uma autocrítica a seu comportamento sexual, Harry toma como modelo aquele que seria o exemplo de moral de sua nação; no entanto, acaba constatando que a realidade é outra. (Vale lembrar que o filme é da década de 1990, mesma época do escândalo de Clinton.)

A oposição scríptica evocada é do tipo real / ideal, podendo ser considerado ideal que o presidente não seja um homem promíscuo e real a constatação de que ele o é. Aliás, o exemplo é também uma piada sexual, podendo ser considerado idial que políticos sejam modelos de comportamento sexual e real a constatação de que possam ser promíscuos.

Em ambas as traduções (cinema e VHS) a estratégia adotada foi a de manutenção, solução coerente, dado que o alvo da alusão provavelmente será reconhecido pelo público brasileiro.

Cabe fazer uma observação sobre as legendas: na tradução para o cinema, os marcadores conversacionais foram omitidos, enquanto que, na tradução para VHS, eles foram mantidos. Muitos teóricos da TAV, como Diaz Cintas (2007), defendem a omissão da maioria dos marcadores para tornar a leitura das legendas menos cansativa.

\subsection{Síntese dos resultados}

Vejamos, agora, o resumo das estratégias tradutórias identificadas no cinema e no VHS. Cabe ressaltar que os exemplos estão em ordem sequencial, independentemente do tipo de humor em que se enquadrem. Em seguida, um resumo do número de vezes em que cada estratégia foi adotada.

\begin{tabular}{|c|c|c|c|c|}
\hline & Original & Recurso linguístico & Estratégia cinema & Estratégia VHS \\
\hline $\begin{array}{l}\text { Ex. } \\
1\end{array}$ & Come & $\begin{array}{l}\text { duplo sentido com } \\
\text { conotação sexual }\end{array}$ & Recriação: & $\frac{\text { Neutralização: }}{\text { Vamos }}$ \\
\hline
\end{tabular}


FERREIRA - O humor na tradução para legendagem...

\begin{tabular}{|c|c|c|c|c|}
\hline $\begin{array}{l}\text { Ex. } \\
2\end{array}$ & $\begin{array}{l}\text { "banging } \\
\text { beaver" } \\
\text { "fuck God" }\end{array}$ & $\begin{array}{l}\text { palavrão } \\
\text { palavrão }\end{array}$ & $\begin{array}{l}\text { Manutenção: } \\
\text { comer xoxota } \\
\text { Manutenção: } \\
\text { Deus que se foda }\end{array}$ & $\begin{array}{l}\text { Omissão: } \\
\text { castor trepador } \\
\text { Neutralização: } \\
\text { Deus que se dane }\end{array}$ \\
\hline $\begin{array}{l}\text { Ex. } \\
3\end{array}$ & $\begin{array}{l}\text { shop at } \\
\text { Victoria's Secret. }\end{array}$ & referente cultural & $\begin{array}{l}\text { Explicitação: } \\
\text { Compram lingerie na } \\
\text { Victoria's Secret. }\end{array}$ & $\begin{array}{l}\text { Manutenção: } \\
\text { compram na } \\
\text { Victoria's Secret. }\end{array}$ \\
\hline $\begin{array}{l}\text { Ex. } \\
4\end{array}$ & $\begin{array}{l}\text { nihilism, } \\
\text { cynicism, } \\
\text { sarcasm and } \\
\text { orgasm. } \\
\text { You know, in } \\
\text { France I could } \\
\text { run on that } \\
\text { slogan and win. }\end{array}$ & $\begin{array}{l}\text { reiteração de sons } \\
\text { comentário espirituoso }\end{array}$ & $\begin{array}{l}\text { Manutenção: } \\
\text { niilismo, cinismo, } \\
\text { sarcarsmo e orgasmo. } \\
\text { Na França, esse slogan } \\
\text { me elegeria. }\end{array}$ & $\begin{array}{l}\text { Manutenção: } \\
\text { niilismo, cinismo, } \\
\text { sarcasmo e orgasmo. } \\
\text { Na França, eu } \\
\text { ganharia com esse } \\
\text { slogan. }\end{array}$ \\
\hline $\begin{array}{l}\text { Ex. } \\
5\end{array}$ & $\begin{array}{l}\text { Not only do I } \\
\text { know that we } \\
\text { lost } 6 \text { million, } \\
\text { but the scary } \\
\text { thing is that } \\
\text { records are } \\
\text { made to be } \\
\text { broken. }\end{array}$ & $\begin{array}{l}\text { comentário absurdo } \\
\text { duplo sentido }\end{array}$ & $\begin{array}{l}\frac{\text { Neutralização/Manutenção: }}{\text { Não só sei que perdemos }} \\
6 \text { milhões... mas o pior é } \\
\text { que recordes existem } \\
\text { para serem quebrados. }\end{array}$ & $\begin{array}{l}\text { Omissão: } \\
\text { Não só sei que } \\
\text { perdemos seis } \\
\text { milhões, mas o pior é } \\
\text { que os registros são } \\
\text { violados. }\end{array}$ \\
\hline $\begin{array}{l}\text { Ex. } \\
6\end{array}$ & Bad example. & alusão & $\begin{array}{l}\text { Manutenção: } \\
\text { Mau exemplo. }\end{array}$ & $\begin{array}{l}\text { Manutenção: } \\
\text { Mau exemplo. }\end{array}$ \\
\hline
\end{tabular}

Tabela 1 - Resumo das estratégias tradutórias

\begin{tabular}{|l|r|}
\hline $\begin{array}{l}\text { Estratégia } \\
\text { tradutória }\end{array}$ & $\begin{array}{l}\text { Número de vezes em } \\
\text { que foi adotada }\end{array}$ \\
\hline manutenção & 4 \\
\hline neutralização & 1 \\
\hline recriação & 1 \\
\hline explicitação & 0 \\
\hline omissão & \\
\hline
\end{tabular}

Tabela 2 - Estratégias da tradução para cinema

\begin{tabular}{|l|r|}
\hline $\begin{array}{l}\text { Estratégia } \\
\text { tradutória }\end{array}$ & $\begin{array}{l}\text { Número de vezes em } \\
\text { que foi adotada }\end{array}$ \\
\hline manutenção & 3 \\
\hline neutralização & 2 \\
\hline omissão & 2 \\
\hline explicitação & 0 \\
\hline recriação & 0 \\
\hline
\end{tabular}

Tabela 3 - Estratégias da tradução para VHS

\section{Conclusões}

A presente pesquisa, voltada para a tradução de humor na legendagem, se desenvolveu em duas etapas. Na primeira, foram analisados alguns mecanismos linguísticos de construção de humor identificados em D.H.; na segunda, foram analisadas duas traduções do filme, no formato de legendas: uma realizada para o cinema, por Monika 
FERREIRA - O humor na tradução para legendagem...

Pecegueiro do Amaral, em maio de 1999, e outra, para VHS, por tradutor anônimo, em data não identificada.

A investigação das situações foi feita, principalmente, com base na teoria semântica do humor de Victor Raskin (1985), na teoria descritivista de tradução de Gideon Toury (1980, 1995) e em alguns estudos sobre tradução audiovisual, como os de Jorge Díaz Cintas (2007), Delia Chiaro (1992, 2009), Jan Pedersen (2005, 2007) e Carolina Alfaro de Carvalho (2005). Além disso, o estudo foi complementado por estudos sobre tradução de humor, como o de Marta Rosas (2002), e pelas teorias de humor de Henri Bergson (1900) e Sigmund Freud (1905).

Respondendo aos questionamentos feitos na Introdução:

a) Foi possível manter os mecanismos linguísticos que construíram as situações de humor no original? Na maioria dos exemplos, sim. Como é possível perceber pelo quadro apresentado anteriormente, a manutenção foi a estratégia mais adotada em ambas as traduções. Alguns mecanismos exigiram dos tradutores algum tipo de mudança em relação ao original, como foi o caso dos duplos sentidos sem equivalente na língua-alvo. Houve dois casos de omissão dos mecanismos linguísticos de construção de humor do original, o que é um número relativamente pequeno (embora o apagamento de qualquer situação de humor do original não seja ideal). Em outros exemplos, como no caso da explicitação do gatilho do original, ou da neutralização da linguagem sexual, uma próxima pesquisa poderá investigar os motivos que levaram os tradutores a realizarem tais mudanças em relação ao original. Ainda assim, os mecanismos linguísticos não foram totalmente omitidos, o que pode ser considerado positivo do ponto de vista do humor.

b) A manutenção garantiu uma situação de humor na tradução? Em muitos casos, sim, pois as traduções mantiveram os elementos fundamentais de um enunciado humorístico (gatilho, oposição scríptica) e poderiam ser reconhecidas como cômicas na cultura-alvo. No caso dos duplos sentidos, percebe-se que em alguns casos os tradutores procuraram manter a situação de humor, principalmente no caso da estratégia de recriação adotada no cinema, que manteve o mecanismo linguístico do original; em outros exemplos, os duplos sentidos foram neutralizados por conta de um obstáculo linguístico. Em um único caso, a omissão do duplo sentido, na tradução para VHS, gerou realmente o apagamento da situação de humor. 
FERREIRA - O humor na tradução para legendagem...

Quanto à linguagem obscena, como foi mantida no cinema, sem dúvidas manteve o elemento humorístico, o fator surpresa. No VHS, em que foi amenizada, talvez não cause tanto impacto, mas ainda assim é potencialmente humorística, pois manteve uma das oposições scrípticas do original; o apagamento do elemento humorístico ocorreu apenas no exemplo em que o tradutor cometeu um erro de tradução.

Espero que a análise possa contribuir para um melhor entendimento do processo geral de tradução para legendas e, mais especificamente, de tradução de diálogos que pretendam despertar o riso em programas audiovisuais.

\section{Referências Bibliográficas:}

BAXTER, J. Woody Allen: a biography. Nova York: Carroll \& Graff Publishers, inc., 1998.

BERGSON, H. O riso: ensaio sobre a significação da comicidade. Tradução Ivone Castilho Benedetti. São Paulo: Martins Fontes, 2007 [1900]. Título original: Le rire.

BJÖRKMAN, S. Woody Allen por Woody Allen. Tradução Eduardo Vivácqua. Rio de Janeiro: Nórdica, 1993. Título original: Woody om Allen.

CARVAlHO, C. A. A tradução para legendas: dos polissistemas à singularidade do tradutor. Dissertação (Mestrado) — Programa de Pós-Graduação em Letras, PUC-Rio, Rio de Janeiro, 2005.

CHIARO, D. Issues in audiovisual translation. In: MUNDAY, J. (org.) Routledge Companion to Translation Studies. Nova York: Routledge, 2009.

The language of jokes: analysing verbal play. Londres e Nova York:

Routledge, 1992.

DÍAZ CINTAS, J.; REMAEL, A. Audiovisual translation: subtitling. Manchester: St. Jerome Publishing, 2007.

FERREIRA, M. P. O humor na tradução para legendagem: o caso de Woody Allen em

Descontruindo Harry. Dissertação (Mestrado) — Programa de Pós-Gradução em Letras, PUC-Rio, Rio de Janeiro, 2010. 
FERREIRA - O humor na tradução para legendagem...

FRANÇA, M. T. A construção lingüística do riso nas crônicas de José Simão. Tese (Doutorado) - Faculdade de Filosofia, Letras e Ciências Humanas, USP, São Paulo, 2006. FREUD, S. Os chistes e sua relação com o insconsciente. Tradução Maria Aparecida Moraes Rego. Rio de Janeiro: Imago Editora LTDA., 2007 [1905]. Título original: Der Witz und seine Beziehung zum Unbewyssten.

GOTTLIEB, H. Subtitling: diagonal translation. In: Perspectives: studies in translatology, v. 2, 1994, pp. 101-121.

LAX, E. Conversas com Woody Allen: seus filmes, o cinema e a filmagem. Tradução José Rubens Siqueira. São Paulo: Cosac Naif, 2009. Título original: Conversations with Woody Allen: his films, the movies and moviemaking.

LIA, C.F. "Bons cidadãos: a comunidade judaica do Rio Grande do Sul durante o Estado Novo (1937-1945)". Tese de doutorado, Pontifícia Universidade Católica do Rio Grande do Sul, PUCRS, Brasil. 2004.

MARTINEZ, S. Tradução para legendas: uma proposta para a formação de profissionais. Dissertação (Mestrado) - Programa de Pós-Gradução em Letras, PUC-Rio, Rio de Janeiro, 2007.

MARTINS, M. A. P. Descriptive translation studies: uma revisão crítica. In: Gragoatá. Niterói, v. 13, pp. 33-52, 2003.

PEDERSEN, J. How is culture rendered in subtitles?. In: MuTra 2005 - Challenges of Multidimensional Translation (Conferência), Saarbrücken, 2005.

Cultural Interchangeability: the effects of subtitling cultural references in subtitling. In: Perspectives, 15, 2007, pp. 30-48.

RASKIN, V. Semantic Mechanisms of Humor. Holanda: D. Reidel Publishing Company, 1985.

ROSAS, M. Tradução de humor: transcriando piadas. Rio de Janeiro: Lucerna, 2002. STONE, J.; ROIG, R. AV translation, audience design, and the risk of condescension: playing to the gallery? In: I Congrés SETAM, Universitat Pompeu Fabra, Barcelona, 2001. TOURY, G. In search of a theory of translation. Tel Aviv: The Porter Institute for Poetics and Semiotics, Tel Aviv University, 1980.

Descriptive translation studies and beyond. Amsterdam/Philadelphia: John Benjamins Publishing Company, 1995. 
FERREIRA - O humor na tradução para legendagem...

VANDAELE, J. “(Re-)Constructing Humour: Meanings and Means”. In: The Translator, vol. 8, n. 2, 2002, pp. 149-172.

American Heritage Dictionary of the English Language

Dicionário Houaiss

Dicionário Aulete Digital

Desconstruindo Harry. Diretor: Woody Allen. Elenco: Woody Allen, Richard Benjamin, Kirstie Alley, Billy Crystal, Demi Moore. Nova York, 1997. VHS (96 min.). Título original: Deconstructing Harry. 